\title{
Use of the Comprehensive Two-Dimensional Gas Chromatography (GCXGC-qMS) to Characterize The Classes of Saturated Compounds in Brazilian crude Oils
}

\author{
Silva, S. R. C.; Borel, L. F. C.; Puziol, L. C.; Sad, C. M. S.; Rodrigues, E. V. A.; \\ Kuster, R. M.; Castro, E. V. R.; Filgueiras, P. R.*
}

Rev. Virtual Quim., 2018, 10 (4), 977-988. Data de publicação na Web: 16 de julho de 2018

http://rvq.sbq.org.br

\begin{abstract}
Uso da Cromatografia Gasosa Bidimensional Abrangente (GCXGC-qMS) para Caracterizar as Classes de Compostos Saturados em Petróleos Brasileiros
\end{abstract}

Resumo: A produção de petróleo brasileiro na camada do pré-sal consiste em óleos com alto teor de compostos saturados. A identificação de compostos parafínicos e naftênicos nesses petróleos é fundamental para entender seu comportamento reológico. No presente estudo, cromatografia gasosa bidimensional abrangente foi aplicada para avaliar a capacidade de separação destes componentes quando comparada a cromatografia gasosa monodimensional. Consequentemente, foi possível estimar de forma relativa as várias classes existentes na fração saturada do petróleo. Os resultados indicam que os compostos naftênicos (53-77\%) são mais abundantes que as $n$-parafinas e as iso-parafinas (22-46\%) nas frações apolares de petróleo em amostras de média a baixa densidade, de acordo com o Instituto Americano do Petróleo (API). Óleos leves apresentaram alta quantidade de iso-parafinas (37\%) e a segunda classe mais abundante foi os compostos monocíclicos (30\%). Petróleos com alto ponto de fluidez apresentaram maior quantidade de $n$-parafinas pesada que petróleos com baixo ponto de fluidez, sugerindo uma correlação entre o ponto de fluidez e as $n$-parafinas de alta massa molar.

Palavras-chave: Cromatografia gasosa bidimensional abrangente; petróleo; saturados.

\section{Abstract}

Brazilian oil production of pre-salt layer consists of oils with high content of saturated compounds. The identification of paraffinic and naphthenic compounds in these crude oils is key to understanding their rheological behavior. In the present study, comprehensive two-dimensional gas chromatography was performed to assess the greater separation capacity of products when compared with one-dimensional gas chromatography. Accordingly, it was possible to estimate relative the various classes existing in the saturated fraction of the crude oil. The results indicate that naphthenic compounds (53-77\%) are more abundant than $n$ paraffins and iso-paraffins (22-46\%) in nonpolar petroleum fractions from medium to low gravity, according American Petroleum Institute (API). Light oils showed high amount of iso-paraffins (37\%), and the second most abundant class was the monocyclic compounds (30\%). Crude oils with high pour point showed higher amount of heavy $n$-paraffins than oils with low pour point, suggesting a correlation between pour point and high molecular weight $n$-paraffins.

Keywords: Comprehensive two-dimensional gas chromatography; crude oil; saturates.

\footnotetext{
* Federal University of Espírito Santo, Laboratory of Research and Development of Methodologies for Analysis of Oils (LabPetro), Chemistry Department, Avenida Fernando Ferrari, 514, Goiabeiras, CEP 29075-910, Vitória-ES, Brazil.

$M$ filgueiras.pr@gmail.com DOI: $\underline{10.21577 / 1984-6835.20180069}$
} 


\title{
Use of the Comprehensive Two-Dimensional Gas Chromatography (GCXGC-qMS) to Characterize The Classes of Saturated Compounds in Brazilian crude Oils
}

\author{
Samantha R. C. Silva, Leandro F. C. Borel, Letícia C. Puziol, Cristina M. S. \\ Sad, Érica V. A. Rodrigues, Ricardo M. Kuster, Eustáquio V. R. Castro, \\ Paulo R. Filgueiras*
}

Federal University of Espírito Santo, Laboratory of Research and Development of Methodologies for Analysis of Oils (LabPetro), Chemistry Department, Avenida Fernando Ferrari, 514, Goiabeiras, CEP 29075-910, Vitória-ES, Brazil.

* filgueiras.pr@gmail.com

Recebido em 1 de fevereiro de 2018. Aceito para publicação em 9 de julho de 2018

1. Introduction

\section{Experimental}

2.1. Crude Oil Samples

2.2. API Gravity

2.3. Pour point

2.4. SAP Fractions

2.5. GCxGC-qMS parameters

\section{Results and discussion}

4. Conclusion

\section{Introduction}

Petroleum is still the most versatile and natural source of fuels and chemicals of vital importance in modern life. Its thousands of compounds may be separated by distillation and extraction into its various fractions, including gases, naphtha, gasoline, kerosene, aviation fuel, lubricants, fuel and asphalt. ${ }^{1}$ Owing to this complex mixture, crude oil composition is usually evaluated by groups of compounds with similar chemical properties, such as saturates, aromatics and polars (SAP), the latter comprising asphaltenes and resins. Saturates include alkanes ( $n$-paraffins), branched (iso-paraffins) and cyclical compounds (cyclo-paraffins). Aromatics consist of aromatic, aromatic-cycloalkane (naphthenic aromatics) and, usually, heterocyclic compounds such as thiocompounds. ${ }^{2}$ Finally, the polar class (resins and asphaltenes) is formed by polycyclic aromatic compounds of high molecular weight, containing larger amounts of heteroatoms. ${ }^{3}$

The physicochemical properties of oils change considerably, depending on the 
content of their main classes of compounds. Therefore, the development of feasible analytical methodologies to determine such content is necessary, essentially because the oil industry must determine the adoption of appropriate procedures for processing and transporting oil. Typically, higher API gravity of oil correlates with a lower amount of aromatic compounds. As such, a higher amount of such lighter compounds as paraffins and isoparaffins will have lower oil viscosity. Apart from density and viscosity, other properties of oils are influenced by their chemical composition, e.g., high levels of high molecular weight $(\mathrm{Mw})$ paraffins raise the melting point of the oil. ${ }^{4}$ Dedicated instruments using multicolumn separation systems have been designed to characterize petroleum fractions $s^{5}$, and the speciation of petroleum constituents provides a better understanding of their physicochemical characteristics, since this factor adds value to the industrial production process. With the advent of comprehensive two-dimensional (2D) gas chromatography coupled to mass spectrometry (GCXGC-MS), even more structural information could be obtained.

Nowadays, GC $\times G C$ is beginning to be successfully applied in advanced laboratories to detect and quantify trace-level constituents and contaminants in several types of matrices. ${ }^{6-11}$ This technique combines two GC columns with different separation mechanisms connected by a modulator, which is a device that traps, focuses and reinjects the components that elute from the first column into the second column. The components eluting from the first column, representing a number of overlapping peaks, is further separated on the second column. The second separation is fast, allowing the introduction of subsequent fractions from the first column without mutual interference. ${ }^{1,2}$ In principle, all kinds of stationary phases can be used in the first dimension of a $G C \times G C$ instrument. The utilization of a nonpolar phase, however, enables minimizing the effect of the activity coefficient in the first dimension. The analytical results show that the separation capacity of the normal phase column becomes higher as the molecular weight and polarity of the hydrocarbons increase and as a consequence of the nearly exponential increase of retention time in the second column. ${ }^{11,12}$

In the present study, we sought to expand available information about the fraction of saturated compounds from Brazilian basin crude oil by modern quadrupole GCXGC (GCxGC-qMS) instrumentation, allowing the separation of the whole saturates into several classes of organic compounds. This can be achieved by the use of scanning speeds that meet the $50 \mathrm{~Hz}$ requirement to reach 10,000 $\mathrm{amu} / \mathrm{s}$ by the proper selection of mass range settings and by the use of mass spectral data for confirmation of the class of the analyzed compound. For the first dimension separation of GC×GC, a DB-5MS (5\% phenyl, 95\% methylpolysiloxane, was used because this phase separates on the basis of volatility. Volatility distribution of an oil sample is an important quality for compound characterization. To provide chromatographic separation of aliphatic and aromatic hydrocarbons, the DB- 5 was combined with a BPX50 $\quad(50 \%$ phenyl polysilphenylenesiloxane) in the second dimension. ${ }^{2}$

\section{Experimental}

\subsection{Crude Oil Samples}

Brazilian crude oils with different physicochemical properties, ranging from light to heavy oil, were used in this study. During the oil treatment process, the free water (non-emulsified water) present in oil was separated by decantation for $1 \mathrm{~h}$, as described by Sad et al. ${ }^{13}$ After that, the water content was determined in the water-in-oil emulsions. Samples with water content more than $2 \% \mathrm{v} / \mathrm{v}$ were dehydrated. Copolymers of polyethylene oxide and polypropylene oxide (PEO-PPO) with different molar ratios of EO/PO were used as surfactants. Demulsification is achieved by adding $200 \mu \mathrm{L}$ of concentrated commercial demulsifier at 60 ${ }^{\circ} \mathrm{C}$ and centrifuging at $1600 \mathrm{rpm}$ for $15 \mathrm{~min}$. 
The resulting product is termed "dehydrated oils". After demulsification, water content was again determined to verify if it was lower than $1.0 \% \mathrm{v} / \mathrm{v}$, as determined by the potentiometric Karl Fischer titration method in accordance with the ASTM D4377 standard method. ${ }^{14}$

\subsection{API Gravity}

API gravity of the samples was determined according to ASTM D1250. ${ }^{15}$ Crude oil samples used in this study were classified as light, medium and heavy (according to ANP classification - National Agency for Oil, Natural Gas and Biofuels). ${ }^{16}$ Samples with high density were measured at $50{ }^{\circ} \mathrm{C}$ and then converted to their equivalent value at $20{ }^{\circ} \mathrm{C}$ to calculate API gravity.

\subsection{Pour point}

The maximum pour point was determined according to ASTM D $5853^{17}$ in a 531/S PETROTEST semi-automatic pour point tester with five test cameras containing four dependent test cells with an applicability range of 20 to -69 oc. The samples were manually homogenized under stirring for 2 min and then transferred to the test flask coupled with a 5 o $C$ thermometer. The test flask containing the sample was left to rest at room temperature for $24 \mathrm{~h}$ to achieve equilibrium between the crystallized wax and dissolved wax. After this period, the test flask was heated at 45 ㅇ $\mathrm{C}$ for $15 \mathrm{~min}$ in an oven. To stop the resting period, the sample was gently stirred with a glass rod, and the walls of the flask were carefully rubbed. The test flask was then inserted into the measurement chamber, and the test was started by lowering the temperature. For every temperature decrease of $3 \stackrel{\circ}{\circ}$, the content of the test flask was poured at an angle of 90 o to observe its fluidity. The test was finished when the sample stopped flowing at a given temperature. The maximum pour point determined by the equipment was $-36 \stackrel{\circ}{\circ}$.

\subsection{SAP Fractions}

SAP fractionation is based on the polarity and adsorption of oil components and their different abilities to act on silica gel and alumina. The fractions are eluted and recovered by a series of nonpolar and polar solvents. Saturated, aromatic and polar (resins and asphaltenes) compounds were obtained by preparative column chromatography on silica gel. ${ }^{18}$ The crude oil $(200 \mathrm{mg}$ ) was dissolved in $n$-hexane and then adsorbed onto the surface of activated silica gel (230 to 400 mesh; SiliCycle ${ }^{\circledR}$ Inc., Quebec, Canada)..$^{13}$ Particle sizes of 230 to 400 mesh (10 g), 100200 mesh $(5 \mathrm{~g})$ and $70-30$ mesh $(5 \mathrm{~g})$ were activated at $120^{\circ} \mathrm{C}$ for 12 hours and poured into a glass column $(250 \times 18 \mathrm{~mm})$. The oil adsorbed on silica gel (oil adsorbate) was transferred to the top of the column and successively eluted with $n$-hexane $(200 \mathrm{ml}), n$ hexane: dichloromethane $200 \mathrm{ml}(1: 1, \mathrm{v} / \mathrm{v})$ and methanol $(200 \mathrm{ml})$ to obtain saturated, aromatic and polar fractions, respectively. Each fraction was rotary evaporated to dryness and then weighed. Each oil was fractionated three times, and percent of weight recovery was normalized for each fraction and recorded in Table 1.

\subsection{GCxGC-qMS parameters}

The GC×GC-qMS system consisted of a gas chromatograph combined with a quadrupole mass spectrometer (Shimadzu GC-MS QP2010 Ultra system) and an AOC-5000 autosampler equipped with a ZX1-GCXGC modulator (Zoex, Houston, TX, USA). The modulator utilized liquid nitrogen for the cold jet and gaseous nitrogen for the hot jet.

The chromatographic separation in the first dimension was performed in a nonpolar column (x-axis) DB-5MS with 5\% phenyl and $95 \%$ methylpolysiloxane $(30 \mathrm{~m} \times 0.25 \mathrm{~mm}$ i.d. 
$\times 0.25 \mu \mathrm{m}$ film thickness, J\&W Scientific, Agilent Technologies, USA), and the second dimension was performed with a more polar column (y-axis) BPX-50 with $50 \%$ phenyl and $50 \%$ methyl-polysiloxane $(1.8 \mathrm{~m} \times 0.1 \mathrm{~mm} \times$ $0.1 \mu \mathrm{m}, \mathrm{SGE}, \mathrm{SGE}$ International, Ringwood,

Australia). The temperature program for the $\mathrm{GC}$ oven began at $70{ }^{\circ} \mathrm{C}$, followed by a temperature rate of $2^{\circ} \mathrm{C} / \mathrm{min}$ until $300^{\circ} \mathrm{C}$ and kept in isothermal condition for $20 \mathrm{~min}$. The injector temperature was $280{ }^{\circ} \mathrm{C}$, and the injection was performed in the splitless mode. Helium was used as a carrier gas at a flow rate of $1.5 \mathrm{~mL} / \mathrm{min}$, and the interface and ion source temperature was maintained in $300^{\circ} \mathrm{C}$. The q-MS was operated in the electron ionization mode with a collected mass range of $\mathrm{m} / \mathrm{z} 50-500$. The ion-source temperature was $230{ }^{\circ} \mathrm{C}$, the applied electron energy was $70 \mathrm{eV}$, and the acquisition rate was 25 spectra/s. The $\mathrm{GC} \times \mathrm{GC}$ modulator period was 6 $\mathrm{s}$ (cold jet) and $300 \mathrm{~ms}$ (hot jet), and the processing of data was done with GC Image software (ZOEX Corporation, Houston, Texas, USA). A 5,000 ppm solution was prepared from the saturated fraction with dichloromethane, and $1 \mu \mathrm{L}$ was injected. The relative quantification of the identified classes of saturates was performed based on the volume of the peak, as determined by GClmage software. After obtaining the volumes for all identified compounds, they were related to the amount of saturates from sample, thereby obtaining a relative percentage of each class of saturate present in the sample. In Figure 1 is shown the identification of components from the GCXGCqMS chromatogram of the saturated fraction of the Oil 7. The identified components were grouped into the classes of compounds most important for crude oil characterization.
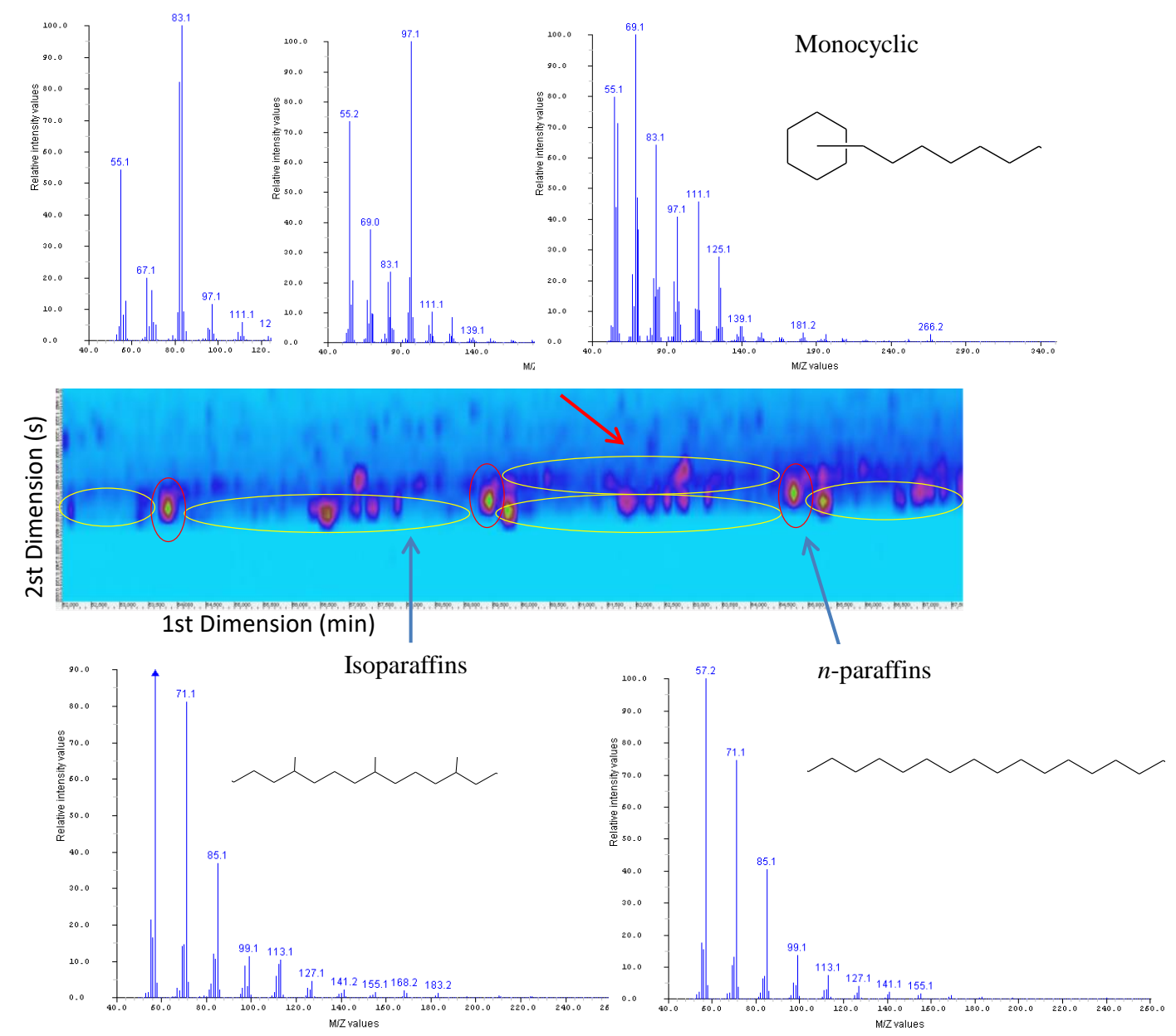

Figure 1. Total Ion Chromatogram (TIC) of some ions identification through the mass spectrum and their hypothetical structure 


\section{Results and discussion}

The GCxGC-qMS technique allowed us to determine the relative presence of most organic compounds in the fraction of saturated petroleum. The determination of the $n$-paraffin distribution in petroleum is important as input in a thermodynamic model to predict the pour point or wax appearance temperature of the oil. The physicochemical properties of the oils are a reflection of their chemical constitution. The aromatic, polar and mainly saturated fractions contain a large amount of chemical compounds which may explain some unexpected compositions of the oil. $^{4}$

The study oils were classified as light (Oil 7, with API gravity greater than 31), intermediate (Oils 1, 2, 3, 4 and 8, with API gravity between 31 and 22), and heavy (Oils 5 and 6 , with API gravity less than 22). ${ }^{19}$ Heavy crude oils typically have higher content of polar compounds (resins and asphaltenes) in their composition, while light oils (greater than 31 and high API gravity) show higher content of saturated compounds. ${ }^{20}$

In general, all oils analyzed had a relative percentage of polar compounds ranging from $8 \%$ to $13 \%$ (Table 1 ). Interestingly, heavier oils (5 and 6) did not show the highest values.
These were attributed to Oils 1 and 2 (12.3\% and $13.2 \%$ ) considered intermediate density. On the other hand, Oil 7, the lightest oil, showed the highest content in saturated compounds and the lowest content in polar compounds, satisfying the general rule. ${ }^{13}$ Its high pour point $\left(6^{\circ} \mathrm{C}\right.$ with API gravity of 34.46$)$, however, was not an expected result for a light oil, ${ }^{13}$ but the result can be explained by the higher amount of heavy $n$-paraffins (C27 C35) when compared the other oils studied (except for Oils 5 and 6 with no content of $n$ paraffins) (Figure 2), as well as the larger amount of iso-paraffins (Figure 3).

Coutinho et al., ${ }^{21}$ did semi-quantification of 12 crude oils and observed that oil with small difference in API gravity showed different profiles of class concentration and that branched alkanes was the major class in crude oil following by n-alkanes. Intermediate Oil 1 , 2 and 3 has a positive pour point (3.0, 6.0 and $3.0^{\circ} \mathrm{C}$ respectively) while the intermediate oil has negative pour point $\left(-12{ }^{\circ} \mathrm{C}\right)$. This pour point variation can be related to different quantity of $n$-alkanes, branched alkanes and naphthenic fractions. Vanini et al., ${ }^{22}$ used polar/non-polar column in GCXGC-TOFMS (GC $\times G C$ with time of flight mass spectrometry) and semi-quantified several compounds in 14 classes ( $n$-paraffins, branched paraffins, alkylmonocyclic among others) analyzing total oil. 
Silva, S. R. C. et al.

Table 1. Physicochemical property of Brazilian oils. The results were expressed by average (standard deviation in parentheses)

\begin{tabular}{|c|c|c|c|c|c|c|c|c|}
\hline $\begin{array}{l}\text { Sample } \\
\text { ID }\end{array}$ & $\begin{array}{c}\text { API } \\
\text { gravity } \\
\text { ASTM } \\
\text { D1250 }\end{array}$ & $\begin{array}{c}\text { TAN } \\
\left.\text { (mg.KOH.g }{ }^{-1}\right) \\
\text { ASTM D664 }\end{array}$ & 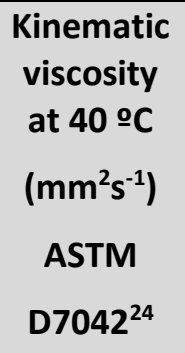 & $\begin{array}{c}\text { Pour } \\
\text { point } \\
\text { (ㄷ) } \\
\text { ASTM } \\
\text { D5853 }{ }^{16}\end{array}$ & $\begin{array}{c}\begin{array}{c}\text { Total } \\
\text { sulphur } \\
\text { (wt\%) }\end{array} \\
\text { ASTM } \\
\text { D4294 }\end{array}$ & $\begin{array}{c}\text { Saturates } \\
\text { (wt\%) }\end{array}$ & $\begin{array}{c}\text { Aromatics } \\
\text { (wt\%) }\end{array}$ & $\begin{array}{l}\text { Polars } \\
\text { (wt\%) }\end{array}$ \\
\hline 1 & 25.63 & $\begin{array}{c}0.236 \\
(0.021)\end{array}$ & $\begin{array}{l}27.51 \\
(0.02)\end{array}$ & 3.0 & $\begin{array}{c}0.4867 \\
(0.0010)\end{array}$ & $\begin{array}{l}63.2 \\
(1.1)\end{array}$ & $\begin{array}{l}24.5 \\
(1.8)\end{array}$ & $\begin{array}{l}12.3 \\
(0.7)\end{array}$ \\
\hline 2 & 27.47 & $\begin{array}{c}0.353 \\
(0.049)\end{array}$ & $\begin{array}{l}21.94 \\
(0.02)\end{array}$ & 6.0 & $\begin{array}{c}0.3879 \\
(0.0003)\end{array}$ & $\begin{array}{l}60.9 \\
(3.8)\end{array}$ & $\begin{array}{l}25.9 \\
(2.2)\end{array}$ & $\begin{array}{l}13.2 \\
(2.0)\end{array}$ \\
\hline 3 & 26.54 & $\begin{array}{c}0.201 \\
(0.030)\end{array}$ & $\begin{array}{l}17.10 \\
(0.23)\end{array}$ & 3.0 & $\begin{array}{c}0.3562 \\
(0.0004)\end{array}$ & $\begin{array}{l}59.8 \\
(1.9)\end{array}$ & $\begin{array}{l}29.0 \\
(1.6)\end{array}$ & $\begin{array}{l}11.3 \\
(0.3)\end{array}$ \\
\hline 4 & 27.88 & $\begin{array}{c}0.314 \\
(0.021)\end{array}$ & $\begin{array}{l}20.42 \\
(0.11)\end{array}$ & -12.0 & $\begin{array}{c}0.3714 \\
(0.0003)\end{array}$ & $\begin{array}{l}65.1 \\
(2.8)\end{array}$ & $\begin{array}{l}25.7 \\
(0.8)\end{array}$ & $\begin{array}{c}9.2 \\
(3.5)\end{array}$ \\
\hline 5 & 16,86 & $\begin{array}{c}2.913 \\
(0.153)\end{array}$ & $\begin{array}{l}550.7 \\
(6.7)\end{array}$ & -21.0 & $\begin{array}{c}0.5588 \\
(0.0008)\end{array}$ & $\begin{array}{l}56.3 \\
(0.3)\end{array}$ & $\begin{array}{l}33.8 \\
(1.2)\end{array}$ & $\begin{array}{c}9.9 \\
(1.0)\end{array}$ \\
\hline 6 & 14.84 & $\begin{array}{c}2.698 \\
(0.201)\end{array}$ & $\begin{array}{c}1674 \\
(2)\end{array}$ & -9.0 & $\begin{array}{c}0.3103 \\
(0.0010)\end{array}$ & $\begin{array}{l}58.2 \\
(1.2)\end{array}$ & $\begin{array}{l}32.2 \\
(0.8)\end{array}$ & $\begin{array}{c}9.5 \\
(0.8)\end{array}$ \\
\hline 7 & 34.46 & $\begin{array}{c}0.095 \\
(0.007)\end{array}$ & $\begin{array}{l}31.13 \\
(0.09)\end{array}$ & 6.0 & $\begin{array}{c}0.0575 \\
(0.0003)\end{array}$ & $\begin{array}{l}78.0 \\
(1.6)\end{array}$ & $\begin{array}{l}14.1 \\
(1.1)\end{array}$ & $\begin{array}{c}7.9 \\
(0.7)\end{array}$ \\
\hline 8 & 27.36 & $\begin{array}{c}0.123 \\
(0.009)\end{array}$ & $\begin{array}{l}20.53 \\
(0.01)\end{array}$ & -15.0 & $\begin{array}{c}0.3308 \\
(0.0003)\end{array}$ & $\begin{array}{l}64.3 \\
(2.1)\end{array}$ & $\begin{array}{l}24.3 \\
(2.2)\end{array}$ & $\begin{array}{l}11.4 \\
(0.1)\end{array}$ \\
\hline
\end{tabular}




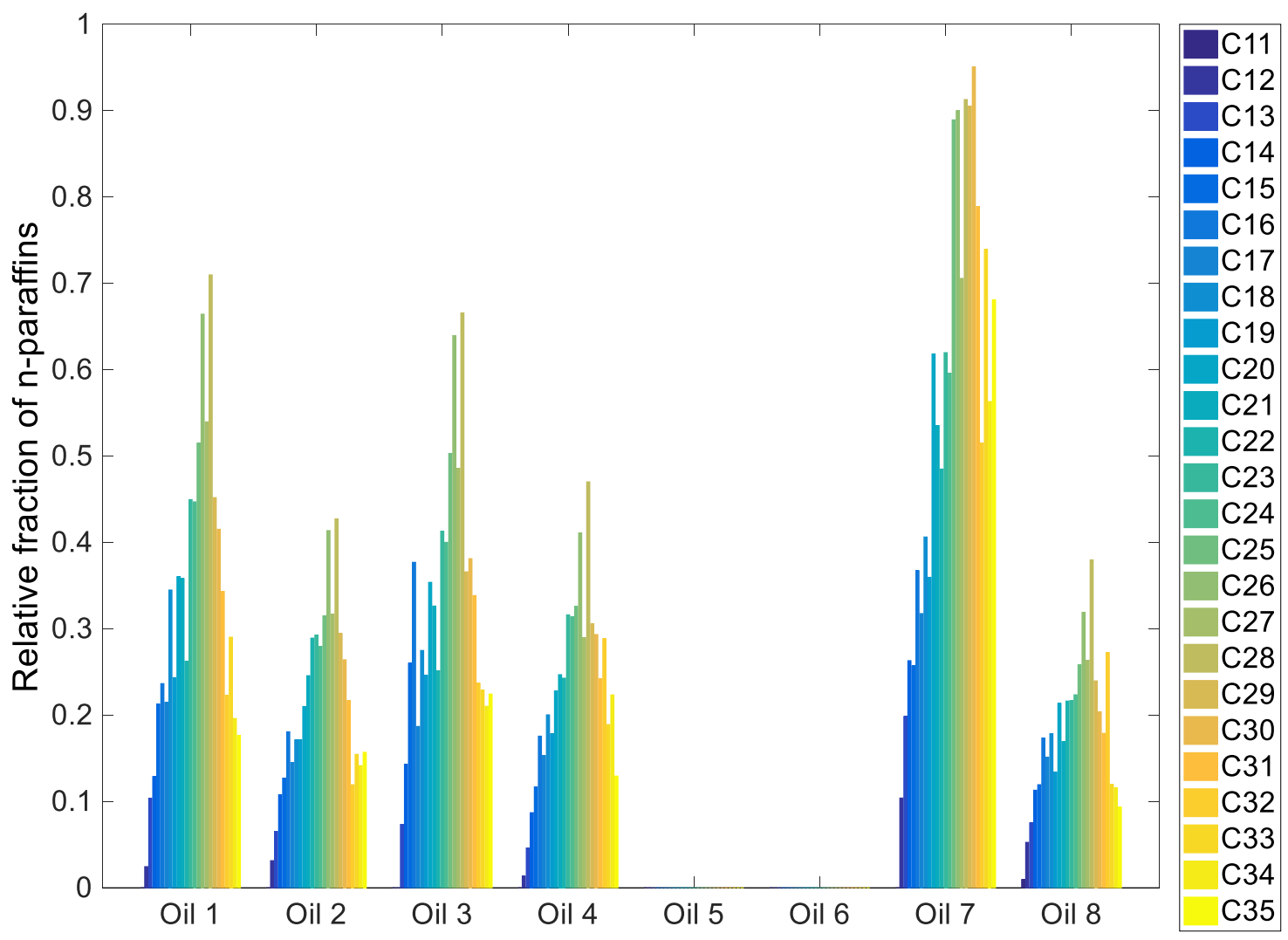

Figure 2. Relative quantification of $n$-paraffins present in the fraction of saturates.

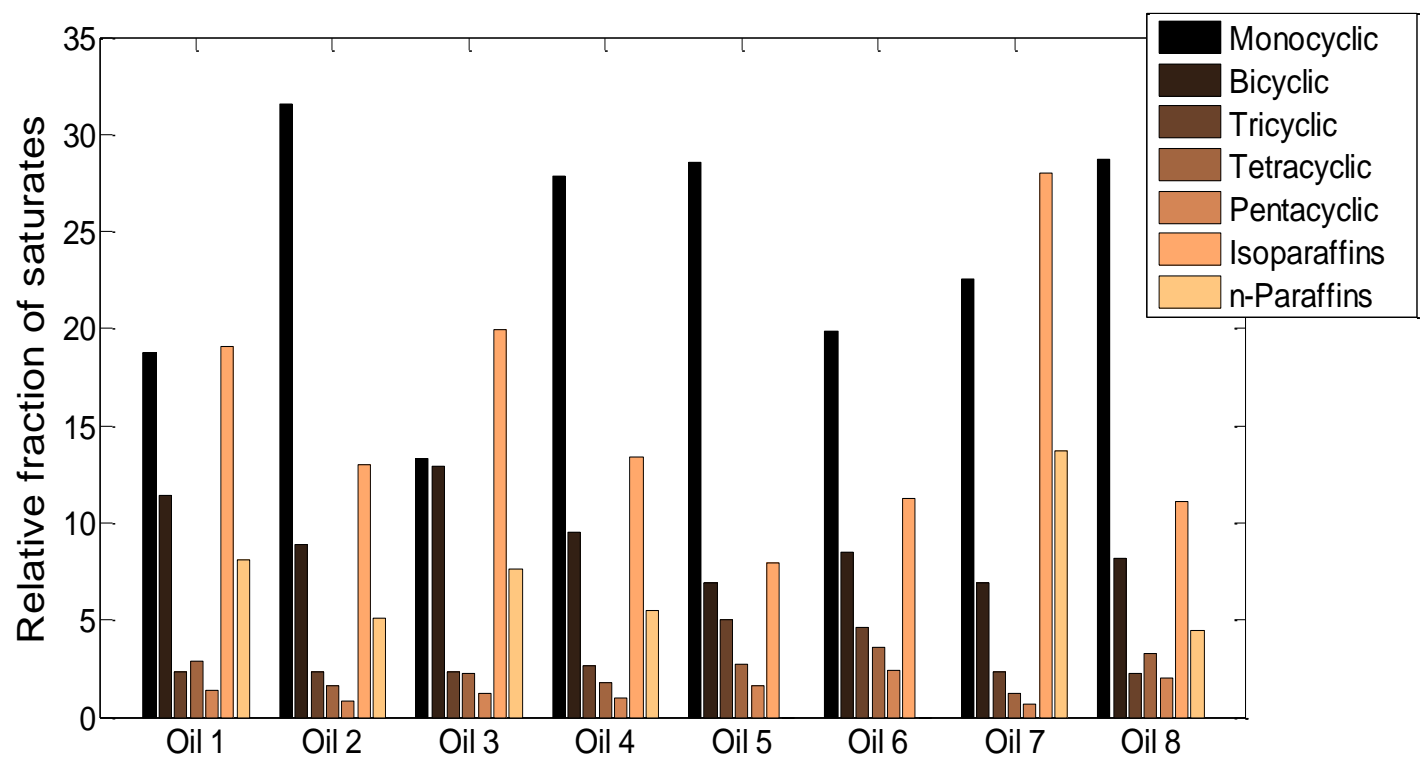

Figure 3. Relative quantification of classes present in the fraction of saturates

Heavy oils (5 and 6) exhibited high kinematic viscosity, as expected, and negative pour point (Table 1$).{ }^{13}$ The absence of $n$ - paraffins in these samples (Figure 2), likely owing to biodegradation processes, appears to have some influence on the low pour 
points. However, the content of aromatics (33.8 wt\% and $32.2 \mathrm{wt} \%$, respectively) was higher in relation to the other oils. Monocyclic naphthenes were also abundant in these samples. Aromatics, along with monocyclic naphthenes, have been described as diesel pour-point depressors. Oils 5 and 6 did not show a sufficient amount of $n$-paraffins for relative quantification as a result of biodegradation. Figure 4 shows a type chromatogram of unresolved complex mixtures (UCM) according to Li et al. (2015). ${ }^{12}$ The other oils have a considerable quantity of $n$-paraffin compounds. According to the scale of biodegradation, ${ }^{26} n$-paraffins are first, followed by iso-paraffins and then the monocyclic class. Oil 5 presents low isoparaffins compounds, while Oil 6 shows no iso-paraffins at all, beginning from monocyclic compounds, as shown in Figure 4.

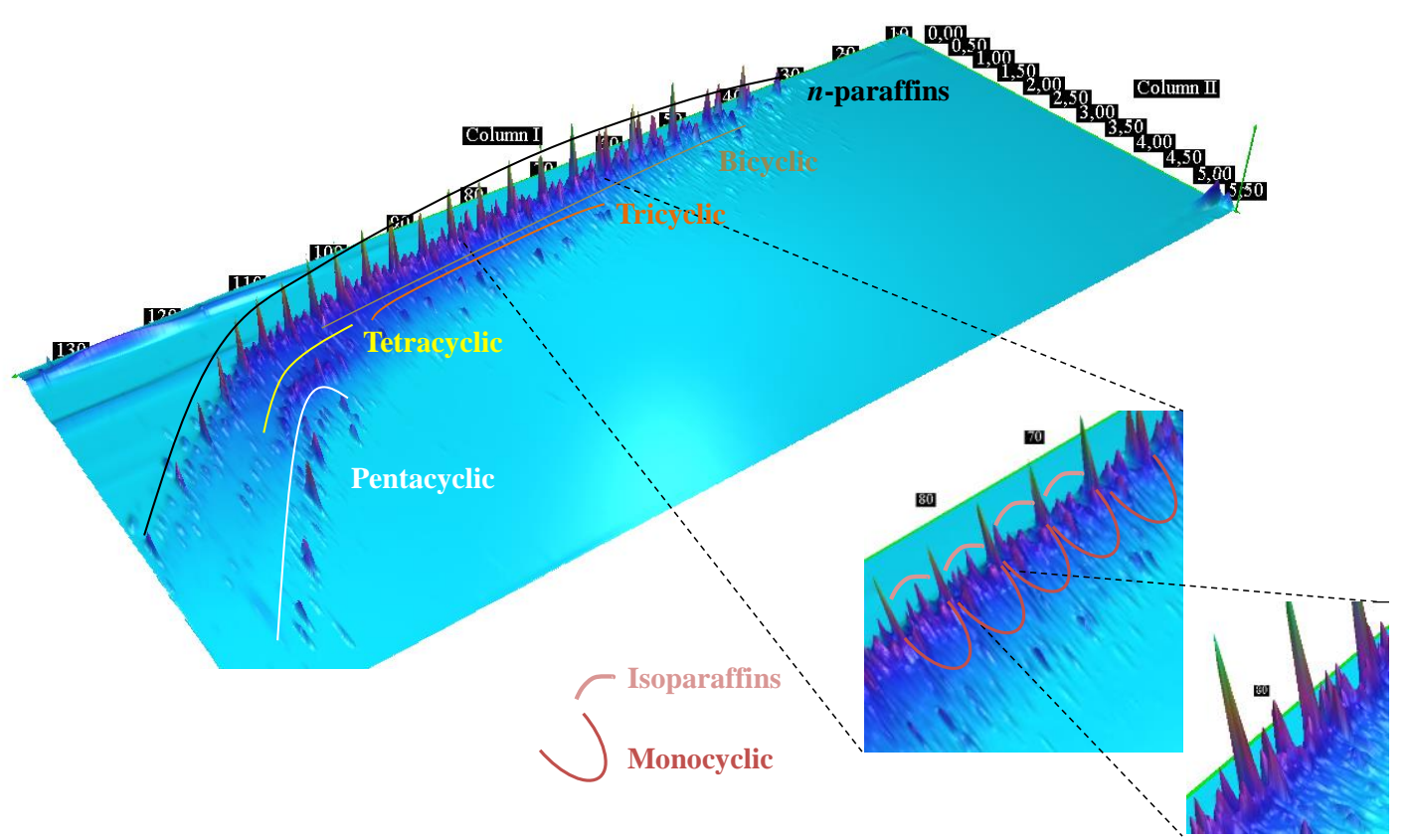

Figure 4. Three-dimensional chromatogram of sample 1, showing the existing classes in greater abundance in the fraction of saturates

Oils 4 and 8 showed low pour point of $-12^{\circ} \mathrm{C}$ and $-15{ }^{\circ} \mathrm{C}$, respectively, as expected for intermediate oils. However, Oils 1, 2 and 3 presented a positive pour point (Table 1), an unexpected result for intermediate oils. This pour point variation for oils within the same class can be relationship with different quantity of $n$-alkanes, branched alkanes and naphthenic fractions. Oils 1,2 and 3 had a relative amount of heavier $n$-paraffin (greater than C23), compared to Oils 4 and 8 (Figure 3 ), while Oil 2 had a high content of monocyclic naphthenes. The higher amount of heavier paraffins was also observed for light Oil 7, which also had a positive pour point.

As saturated compounds, all analyzed oils showed $n$-paraffins, except for the biodegraded Oils 5 and 6, iso-paraffins, and mono-, bi-, tri-, tetra- and pentacyclic naphthenes. Of the naphthenic class, monocyclics were the most abundant among the eight analyzed oils. However, in Oil 3, the bicyclic naphthenes were almost as abundant as the monocyclic naphthenes. Ion fragments with characteristic mass/charge ratios were used to find the several classes of saturated compounds on the chromatogram; $\mathrm{m} / \mathrm{z} 85$ for the $n$-paraffins, $m / z 113,137,183$ for the isoparaffins, $m / z 69,83,97$ for the monocyclic, $m / z 123$ for the bicyclic, $m / z 191$ for the tricyclic, $m / z 217,218$ for the tetracyclic, and $\mathrm{m} / \mathrm{z} 191$ for the pentacyclic compounds, ${ }^{20,27}$ as shown in Figure 4 and 5. 


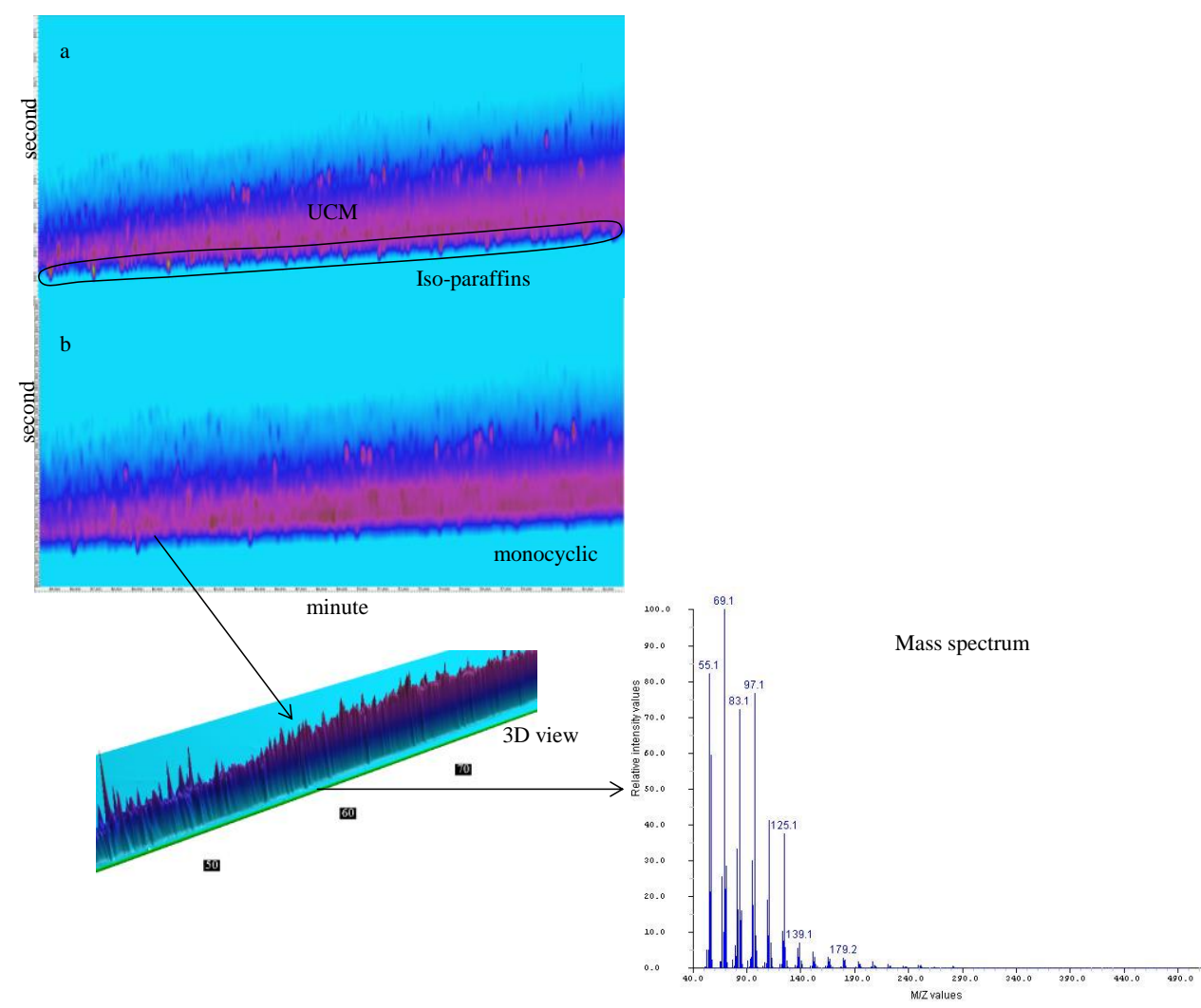

Figure 5. Two-dimensional chromatogram (TIC) for heavy oils (a) sample 5 and (b) sample 6. a) show the presence of iso-paraffins forward and $b$ ) showing the presence of monocyclic compounds forward

\section{Conclusion}

The GCxGC-qMS technique allows the recognition and relative quantification of nonpolar components present in the saturated fraction from petroleum as $n$ paraffins of C11 to C35. In addition, it allows the determination of bicyclic, tricyclic, tetracyclic and pentacyclic compounds. The class of monocyclic and iso-paraffins compounds are the most abundant in the saturated fraction for these oils. The positive pour point for light oils (API gravity greater than 30) may be related to high contents of $n$ paraffins and iso-paraffins.

\section{Acknowledgments}

The authors thank LABPETRO-UFES and Petróleo Brasileiro S.A. (PETROBRAS/CENPES) for providing the crude oil samples, NCQP/UFES for analysis, CAPES and CNPq for financial support (CNPq process number 422515/2016-7).

\section{References}

${ }^{1}$ Xu Z.; Van Den Berg F. G. A.; Sun X.; Xu C.; Zhao $S$. Detailed characterization of virgin heavy oil resid and its thermally cracked resid. Energy and Fuels 2014, 28, 1664. [CrossRef]

${ }^{2}$ Van De Weghe H.; Vanermen G.; Gemoets J.; Lookman R.; Bertels D. Application of comprehensive two-dimensional gas Rev. Virtual Quim. |Vol 10| | No. 4| |977-988| 
chromatography for the assessment of oil contaminated soils. Journal of Chromatography A 2006, 1137, 91. [CrossRef]

${ }^{3}$ Speight J. G. Petroleum asphaltenes - Part 2: The effect of asphaltenes and resin constituents on recovery and refining processes. Oil and Gas Science Technology 2004, 59, 479. [CrossRef]

${ }^{4}$ Coto B.; Coutinho J. A. P.; Martos C.; Robustillo M. D.; Espada J. J.; Peña J. L. Assessment and improvement of $n$-paraffin distribution obtained by HTGC to predict accurately crude oil cold properties. Energy and Fuels 2011, 25, 1153. [CrossRef]

${ }^{5}$ Beens J.; Blomberg J.; Schoenmakers P. J. Proper tuning of comprehensive twodimensional gas chromatography (GC $\times \mathrm{GC}$ ) to optimize the separation of complex oil fractions. Hrc-Journal High Resolution Chromatography 2000, 23, 182. [CrossRef]

${ }^{6}$ Meinert, C.; Meierhenrich, U. J. A new dimension in separation science: Comprehensive two-dimensional gas chromatography. Angewandte Chemie International Edition Ed. 2012, 51, 10460. [CrossRef] [PubMed]

${ }^{7}$ Kueh A. J.; Marriott P. J.; Wynne P. M.; Vine J. H. Application of comprehensive twodimensional gas chromatography to drugs analysis in doping control. Journal of Chromatography A 2003, 1000, 109. [CrossRef]

${ }^{8}$ Cortes H. J.; Winniford B.; Luong J.; Pursch M. Comprehensive two dimensional gas chromatography review. Journal of Separation Science 2009, 32, 883. [CrossRef]

${ }^{9}$ Harynuk J.; Vlaeminck B.; Zaher P.; Marriott P.J. Projection of multidimensional GC data into alternative dimensions-exploiting sample dimensionality and structured retention patterns. Analytical and Bioanalytical Chemistry 2006, 386, 602. [CrossRef]

${ }^{10}$ Marriott P.; Shellie R. Principles and applications of comprehensive twodimensional gas chromatography. Trends Analytical Chemistry 2002, 21, 573. [CrossRef] ${ }^{11}$ Amador-Munoz O.; Villalobos-Pietrini R.; Antonio A.-P.; Tran T. C.; Morrison P.; Marriott P. J. Quantification of polycyclic aromatic hydrocarbons based on comprehensive twodimensional gas chromatography-isotope dilution mass spectrometry. Journal of Chromatography A 2008, 1201, 161. [CrossRef]

${ }^{12}$ Li S.; Cao J.; Hu S.; Luo G. Characterization of compounds in unresolved complex mixtures (UCM) of a Mesoproterzoic shale by using GCxGC-TOFMS. Marine and Petroleum Geology 2015, 66, 791. [CrossRef]

${ }^{13}$ Sad C. M. S.; Jr V. L.; Filgueiras P. R.; Rigoni V. S.; Bassane F. P.; Castro V. R.; Pereira K. S.; Santos M. F. P. Limitations of the pour point measurement and the influence of the oil composition on its detection using principal component analysis. Energy and Fuels 2014, 28, 1686. [CrossRef]

${ }^{14}$ ASTM D4377-00(2011), Standard Test Method for Water in Crude Oils by Potentiometric Karl Fischer Titration, ASTM International, West Conshohocken, PA, 2011. [CrossRef]

${ }^{15}$ ASTM D1250-08(2013), Standard Guide for Use of the Petroleum Measurement Tables, ASTM International, West Conshohocken, PA, 2013. [CrossRef]

${ }^{16}$ Sítio da Agência Nacional do Petróleo, Gás Natural e Biocombustíveis. Disponível em: <http://www.anp.gov.br/glossario\#gloss-P >.

Acesso em: 25 abril 2018.

${ }^{17}$ ASTM D5853-16, Standard Test Method for Pour Point of Crude Oils, ASTM International, West Conshohocken, PA, 2016. [CrossRef]

${ }^{18}$ Filgueiras P. R.; Portela N. A.; Silva S. R. C.; Castro E. V. R.; Oliveira L. M. S. L.; Dias J. C. M.; Neto A. C.; Romão W.; Poppi R. J. Determination of saturates, aromatics and polars in crude oil by ${ }^{13} \mathrm{C}$ NMR and support vector regression with variable selection by genetic algorithm. Energy Fuels 2016, 30, 1972. [CrossRef]

${ }^{19}$ Tozzi F. C.; Sad C. M. S.; Bassane J. F. P.; Dos Santos F. D.; Silva M.; Filgueiras P. R.; Dias H. P.; Castro E. V. R.; Romão W.; Jr V. L. Improving the physicochemical properties of Brazilian onshore and offshore crude oils using the production of blends. Fuel 2015, 159, 607. [CrossRef]

${ }^{20}$ Wang Z.; Stout S.A.; Fingas M. Forensic Fingerprinting of Biomarkers for Oil Spill Characterization and Source Identification. Environmental Forensics 2006, 7, 105. [CrossRef] 
${ }^{21}$ Coutinho D. M.; França D.; Vanini G.; Mendes L. A. N.; Gomes A. O.; Pereira V. B.; Ávila B. M. F.; Azevedo D. A. Rapid hydrocarbon group-type semi-quantification in crude oils by comprehensive twodimensional gas chromatograpy. Fuel 2018, 220, 379. [CrossRef]

${ }^{22}$ Vanini G.; Pereira V. B.; Romão W.; Gomes A. O.; Oliveira L. M. S. L.; Dias J. C. M.; Azevedo D. A. Analytical advanced techniques in the molecular-level characterization of Brazilian crude oils. Microchemical Journal 2018, 137, 111. [CrossRef]

${ }^{23}$ ASTM D664-11ae1, Standard Test Method for Acid Number of Petroleum Products by Potentiometric Titration, ASTM International, West Conshohocken, PA, 2011. [CrossRef] ${ }^{24}$ ASTM D7042, Standard test method for dynamic viscosity and density of liquids by stabinger viscometer (and the calculation of kinematic viscosity). West Conshohocken, PA, 2012. [CrossRef]

${ }^{25}$ ASTM D4294-08, Standard Test Method for Sulfur in Petroleum and Petroleum Products by Energy Dispersive X-ray Fluorescence Spectrometry, ASTM International, West Conshohocken, PA, 2008. [CrossRef]

${ }^{26}$ Larter S.; Huang H.; Adams J.; Bennett B.; Snowdon L.R. A pratical biodegradation scale for use in reservoir geochemical studies of biodegraded oils. Organic Geochemistry 2012, 45, 66. [CrossRef]

${ }^{27}$ Ventura G. T.; Kenig F.; Reddy C. M.; Frysinger G. S.; Nelson R. K.; Mooy B. Van, Gaines G. S. Analysis of unresolved complex mixtures of hydrocarbons extracted from Late Archean sediments by comprehensive twodimensional gas chromatography (GCXGC). Organic Geochemistry 2008, 39, 846. [CrossRef] 